\title{
АНАЛИЗ МЕТОДОВ ОПРЕДЕЛЕНИЯ ТЕМПЕРАТУРЫ НАСЫЩЕНИЯ НЕФТИ ПАРАФИНОМ
}

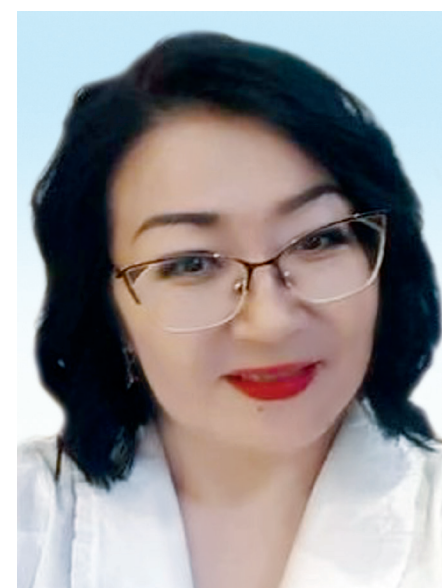

М.К. КАРАЖАНОВА ${ }^{1}$, доцент кафедры «Нефтехимический инжиниринг», https://orcid.org/0000-00023451-9746

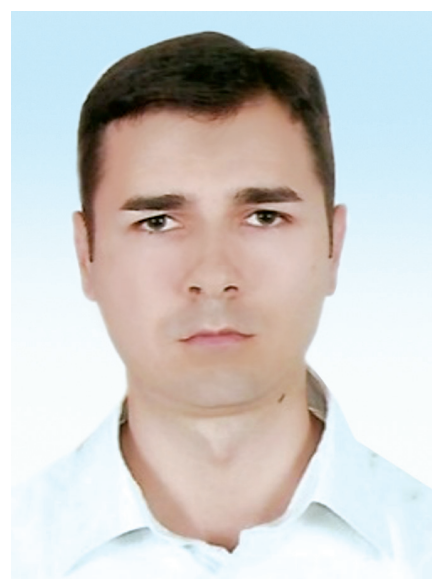

\section{О.Г. КИРИСЕНКО ${ }^{1,2 *}$,} доктор-PhD по техническим наукам, ведущий научный сотрудник, https://orcid.org/0000-00034688-1117

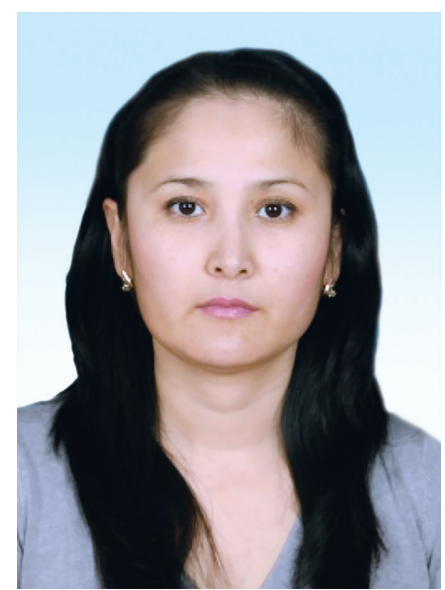

Л.Б. ЖЕТЕКОВА ${ }^{1}$, магистр, докторант, https://orcid.org/0000-00028257-4205

Д.Б. СмАГУЛОВА ${ }^{3}$, магистрант

$$
\begin{gathered}
\text { 1УНИВЕРСИТЕТ ЕСЕНОВА, } \\
\text { Республика Казахстан, г. Актау, } 32 \text { мкр., гл. корпус } \\
\text { ИНСТИТУТ НЕФТИ И ГАЗА НАН АЗЕРБАЙДЖАНА, } \\
\text { Азербайджан, АZ1000, г. Баку, ул. Ф. Амирова, } 9
\end{gathered}
$$

\begin{abstract}
ЗАТЫРАУСКИЙ УНИВЕРСИТЕТ НЕФТИ И ГАЗА ИМЕНИ САФИ УТЕБАЕВА, Республика Казахстан, Атырауская область, г. Атырау, мкр. Привокзальный, ул. Мусы Баймуханова 45a/1.
\end{abstract}

Статья посвящена исследованию влияния асфральтенов, смол и парафинов на показатели свойств нефттей. Борьба с отложениями асфральто-смоло-парафринов усложняется в связи с недостаточной изученностью механизма их фрормирования, их влияния на показатели свойств нефртей, в частности, температуру насыщения нефрти парафином, при изучении закономерностей которых, как показывают исследования, наблюдается отсутствие единого мнения.

Выполнены обобщение и анализ методов и методических подходов при оценке влияния асфральтенов, смол и парафинов на температуру насыщения нефрти парафином. Проведен анализ накопленных результатов экспериментальных исследований для Урало-Поволжья. Для облегчения прогнозной оценки на основе рассмотренных частных зависимостей путем их обобщения и статистического анализа построена общая зависимость температуры насыщения нефти залежей парафином от концентраций асфральтенов, смол, высокомолекулярных парафинов соответственно.

* Адрес для переписки. E-mail: oleg.kirisenko@gmail.com 
Для получения такой зависимости вначале выбраны аналитические аппроксимации частных зависимостей, которые впоследствии обобщены известными в математической статистике методами путем их переумножения. В результате отмеченных преобразований получено уточненное выражение.

Расчеты по полученному выражению дают удовлетворительные результаты. Оmмеченное выражение может быть использовано при ориентировочных расчетах. При этом относительная погрешность колеблется в пределах 4-16\%, что позволяет применять данное выражение. Для получения более точных прогнозных данных о значениях температуры насыщения нефти парафрином необходимы постановка и проведение более детальных, расширенных экспериментальных исследований.

Следует отметить, что знание температуры насыщения нефрти парафрином необходимо для контроля продукции в процессе добычи и принятия необходимого решения по предотвращению и профилактике образования АСПО.

КЛЮЧЕВЫЕ СЛОВА: нефрть, асфральтены, смолы, парафины, температура насыщения нефрти парафрином.

\title{
МҰНАЙДЫҢ ПАРАФИНМЕН ҚАНЫҒУ ТЕМПЕРАТУРАСЫН АНЫҚТАУ ӘДІСТЕРІН ТАЛДАУ
}

М.К. КАРАЖАНОВА ${ }^{1}$, мұнай-химия инжинирингі» кафедрасының доценті, https://orcid. org/0000-0002-3451-9746;

О.Г. КИРИСЕнкО ${ }^{1,2}$, техникалық ғылымдар бойынша $\mathrm{PhD}$ докторы, жетекші ғылыми қызметкер, https://orcid.org/0000-0003-4688-1117;

Л.Б. ЖЕТЕКОВА ${ }^{1}$, магистр, докторант, https://orcid.org/0000-0002-8257-4205;

Д.Б.СМАГУЛОВА ${ }^{3}$, магистрант

\author{
${ }^{1}$ ECEHОВ УНИВЕРСИТЕТІ, \\ Қазақстан Республикасы, Ақтау қаласы, 32 ш/а, бас корпус 2 \\ 2ӘЗІРБАЙЖАН ҰҒА МҰНАЙ ЖӘНЕ ГАЗ ИНСТИТУТЫ, \\ Әзірбайжан, Az1000, Баку қаласы, Ф. Амиров к-сі, 9
}

\begin{abstract}
${ }^{3}$ САФИ ӨТЕБАЕВ АТЫНДАҒЫ АТЫРАУ МҰНАЙ ЖӘНЕ ГАЗ УНИВЕРСИТЕТІ,
Қазақстан Республикасы, Атырау қаласы, Муса Баймуханов көш., 45a/1.
\end{abstract}

Мақала асфальтендердің, шайырлар мен парафиндердің мұнай қасиеттерінің көрсеткіштеріне әсерін зерттеуге арналған. Асфральт-шайыр-парафиндердің шөгінділерімен күрес олардың қалыптасу механизмін, олардың мұнай қасиеттерінің көрсеткіштеріне әсерін, атап айтқанда, мұнайдың парафринмен қанығу температурасын жеткіліксіз зерттеуге байланысты күрделене түседі, олардың заңдылықтарын зерттеу кезінде, зерттеулер көрсеткендей болып отыр. Бұл зерттеушілердің мұнайды өндіруге байланысты проблемаларға назар аударылуымен түсіндіреді. Асфральтендердің, шайырлар мен парафиндердің мұнайдың парафринмен қанығу температурасына әсерін бағалау кезінде әдістер мен әдістемелік тәсілдерді жалпылау және талдау жүргізілді. Орал-Поволжья аймағы үшін эксперименттік зерттеулердің жинақталған нәтижелеріне талдау жасалды. Қарастырылған жеке тәуелділіктердің негізінде оларды жалпылау және статистикалық талдау арқылы болжамды бағалауды жеңілдету үшін парафинмен кен орындарындағы мұнайдың қанығу температурасының асфальтендер, шайырлар, жоғары молекулалық парафиндер концентрациясына жалпы тәуелділігі құрылды.

Мұндай тәуелділікті алу үшін алдымен жеке тәуелділіктердің аналитикалық жуықтаулары таңдалады, олар кейіннен математикалық статистикада белгілі әдістермен оларды көбейту арқылы жалпыланады. Аталған өзгерістердің нәтижесінде нақтыланған есептеу алынды.

Алынған өрнек бойынша есептеулер жалпы қанағаттанарлық нәтиже береді. Белгіленген өрнекті шамамен есептеулер үшін қолдануға болады. Бұл жағдайда салысты- 
рмалы қателік 4-16\% аралығында болады, бұл осы өрнекті қолдануға мүмкіндік береді. Мұнайдың парафинмен қанығу температурасының мәндері туралы неғұрлым нақты болжамды деректерді алу үшін неғұрлым егжей-тегжейлі, кеңейтілген эксперименттік зерттеулер жүргізу қажет.

Мұнайдың парафринмен қанығу температурасын білу қажет екенін атап өткен жөн, ал бұл өз кезегінде өндіру процесінде өнімді бақылауға және АШПШ түзілуінің алдын алу және алдын алу бойынша тиісті қажетті шешімдер қабылдауға мүмкіндік береді.

ТҮЙІн СӨзДЕР: мұнай, асфральтендер, шайырлар, парафиндер, мұнайдың парафинмен қанығу температурасы.

\section{ANALYSIS OF METHODS FOR DETERMINING THE TEMPERATURE OF OIL SATURATION WITH PARAFFIN}

M.K. KARAZHANOVA ${ }^{1}$, associate Professor of the Department of Petrochemical Engineering», https://orcid.org/0000-0002-3451-9746;

O.G. KIRISENKO ${ }^{1,2}$, doctor-PhD in Technical Sciences, Leading researcher, https://orcid. org/0000-0003-4688-1117;

L.B. ZHETEKOVA 1 , master's degree, doctoral degree, https://orcid.org/0000-0002-8257-4205

D.B. SMAGULOVA ${ }^{3}$, master's degree student

${ }^{1}$ YESSENOV UNIVERSITY,

130000, The Republic of Kazakhstan, Aktau, 32 md., Main building

${ }^{2}$ INSTITUTE OF OIL AND GAS OF THE NATIONAL ACADEMY OF SCIENCES OF AZERBAIJAN,

9, F.Amirov str., Baku, AZ1000, Azerbaijan

${ }^{3}$ SAFI UTEBAYEV ATYRAU UNIVERSITY OF OIL AND GAS, 060027, Republic of Kazakhstan, Atyrau, md. Privokzalnyi, st. M. Baimukhanov, 45A/1

The article is devoted to the study of the influence of asphaltenes, resins and paraffins on indicators of oil properties. The struggle against asphaltene-resin-paraffin deposits is complicated due to the insufficient study of the mechanism of their formation, their influence on indicators of oil properties, in particular, the temperature of oil saturation with paraffin, when studying the laws of which, as shown by studies, there is a lack of consensus. This explains the attention of researchers to the problems associated with the production of hard-to-recover oil. A generalization and analysis of methods and methodological approaches in assessing the impact of asphaltenes, resins and paraffins on the temperature of oil saturation with paraffin. An analysis of the accumulated results of experimental studies for the Ural-Volga region. To facilitate the predictive assessment on the basis of the considered individual dependences by their generalization and statistical analysis, a general dependence of the oil saturation temperature of deposits of paraffin from the concentrations of asphaltenes, resins, high-molecular paraffins, respectively, is constructed.

In order to obtain such dependence, analytical approximations of particular dependences were chosen at first, which were subsequently generalized by methods known in mathematical statistics by means of their multiplication. As a result of the mentioned transformations, a refined expression has been obtained.

Calculations according to the obtained expression give, as a whole, satisfactory enough results. The expression noted can be used in the approximate calculations. In this case, the relative error varies from 4 to $16 \%$, which allows us to apply this expression. In order to obtain more accurate predictive data about the values of the temperature of oil saturation with paraffin, it is necessary to set and conduct more detailed, extended experimental studies.

It should be noted that the knowledge of the temperature of oil saturation with paraffinis necessary, and this, in turn, will allow to control products in the process of production and to make appropriate decisions on preventing and preventing ARPD formation.

KEY WORDS: oil, asphaltenes, resins, paraffins, temperature of oil saturation with paraffin. 

усложняется в связи с недостаточной изученностью механизма их формирования, их влияния на показатели свойств нефтей, в частности, температуру насыщения нефти парафином, при изучении закономерностей которых, как показывают исследования, наблюдается отсутствие единого мнения. Этим и объясняется внимание исследователей к проблемам, связанным с добычей трудноизвлекаемых нефтей. В связи с отмеченным в настоящей статье выполнены обобщение и анализ методов и методических подходов при оценке влияния асфальтенов, смол и парафинов на температуру насыщения нефти парафином.

Состояние изученности влияния асфальтенов, смол и парафинов на температуру насыщения нефти парафином. Проводя анализ понятия «трудноизвлекаемые запасы», необходимо заметить, что согласно мнению большинства исследователей за последние десятилетия это понятие претерпело значительные изменения [1]. Сегодня нефтяные компании всерьез задумываются о разработке пластов, которые ранее зачастую не относили даже к потенциальным коллекторам. Единой классификации трудно извлекаемых запасов не существует - много факторов, в том числе и экономических, влияет на степень трудности добычи нефти или газа на каждом конкретном месторождении. Но можно выделить общие критерии: ТРИЗы - это запасы, заключенные в геологически сложно построенных пластах и залежах или представленные малоподвижной (тяжелой, высоковязкой) нефтью. Как правило, они характеризуются сравнительно низкими дебитами скважин и медленными темпами разработки, обусловленными низкой продуктивностью пластов, неблагоприятными условиями залегания нефти или ее аномальными физико-химическими свойствами. Играют свою роль и отсутствие соответствующих технологий, адаптированных для добычи ТРИЗов, и низкая рентабельность подобных разработок. Опережающий отбор нефти из высокопроницаемых коллекторов неоднородных по проницаемости пластов привел к расчленению и разбиению ранее единого нефтенасыщенного поля и образованию отдельных участков. Причем это явление способствовало ухудшению структуры запасов и увеличению доли трудно извлекаемых [2-5]. Однако на ухудшение структуры запасов повлияли также расчлененность коллекторов, их неоднородность и прерывистость. Судя по литературным данным, при исследованиях трудноизвлекаемых нефтей сформировались две группы работ: работы, посвященные исследованиям свойств и условий залегания нефтей и работы, посвященные исследованиям составов нефтей. Аномально-вязкие свойства нефтей, особенно содержащих асфальто-смолистые вещества, усиливаются при охлаждении нефти не только из-за ослабления Броуновского движения, но и из-за появления новой фазы - парафина, отмечается в работе [5] со ссылкой на выполненную ранее работу.

При этом надо иметь в виду, что температура среды должна быть ниже температуры насыщения нефти парафином. Согласно [5], «...по утверждению И.М. Амерханова [6], выявлена связь между температурой насыщения парафином и массовым содержанием асфальто-смолистых веществ и парафина в нефти. Величина температуры насыщения нефти парафином тесно связана с массовым содержанием 
асфальтенов и парафинов и слабо связана с наличием смол.». Причем отмечается, что с ростом массового содержания асфальтенов (до 5 - 6\%) температура насыщения парафином снижается от $32-37^{\circ} \mathrm{C}$ до $20-22^{\circ} \mathrm{C}$ [6,7]. В работе [6] изучено влияние состава высокомолекулярных компонентов на температуру насыщения парафином нефти залежей Урало-Поволжья. В результате наблюдений получены графики зависимости температуры насыщения нефти парафином от содержания асфальтенов, смол и высокомолекулярных парафинов, которые показывают, насколько тесна та или иная зависимость.

В работах [2,3] рассмотрены различные методы разработки месторождений с нефтью повышенной и высокой вязкости, а также некоторые методы разработки месторождений природных битумов. Следует отметить то, что методы разработки битумных месторождений могут существенно отличаться от методов разработки месторождений вязких нефтей, но в некоторых случаях методы могут быть применимы как к одним, так и другим месторождениям. На выбор метода главным образом влияют геолого-физические свойства нефтесодержащих коллекторов и физические свойства насыщающего флюида. Поэтому исследователи посвящают свои работы изучению геолого-физических условий, свойств нефтей различных месторождений. Так, в работе [9] на основе исследований нефтей пяти месторождений Казахстана и сравнительного анализа результатов исследования температур плавления выделенных из нефти парафинов установлено, что данный показатель для месторождения Узень соответствует $48^{\circ} \mathrm{C}$, а Ботахан $44^{\circ} \mathrm{C}$. Парафины с такой температурой плавления при нагреве переходят, естественно, из твердого состояния в жидкое. Согласно данным, приведенным в [9], температура плавления парафинов месторождений Восточный Макат, Кумколь и Акшабулак равна $62^{\circ} \mathrm{C}, 55^{\circ} \mathrm{C}$ и $44^{\circ} \mathrm{C}$ соответственно, как показали результаты термического анализа смол, как для месторождения Ботахан, так и для месторождения Узень, температура плавления смол равна $62^{\circ} \mathrm{C}$ [9]. На основе обработки данных о температурных свойствах выделенных парафинов из нефти, а также реологических параметров нефти была рассчитана температура насыщения нефти парафином, результаты приведены в работе [10]. Анализ литературных источников свидетельствует о большом внимании к данной проблемеи различных попытках описания зависимостей для расчета температуры насыщения в пластовых и поверхностных условиях. В работе [10] приводится краткий обзор этих зависимостей. Так, согласно [9] авторы работы [11] предлагают использовать в качестве уравнения для расчета температуры насыщения нефти парафином по выражению ВНИИнефть [14]:

$$
\mathrm{t}_{\mathrm{o}}=11,398+34,084 \cdot \lg \mathrm{C}_{\mathrm{n}}
$$

где $\mathrm{t}_{\mathrm{o}}$ - температура насыщения нефти парафином в поверхностных условиях; $\mathrm{C}_{\text {п }}$ концентрация парафина в нефти, мас.\%.

Также в литературе приводятся схожие эмпирические зависимости температуры насыщения от содержания парафинов в виде [17]:

$$
\mathrm{t}_{\mathrm{o}}=19,457 \cdot \ln \left(\mathrm{C}_{\mathrm{\Pi}}\right)-0,8117
$$


В работах $[13,15]$ сделан вывод о том, что температура насыщения нефти парафином зависит не только от содержания в ней парафина, но и от присутствия смол и асфальтенов, температуры плавления выделенного парафина из нефти, кинематической вязкости при $20^{\circ} \mathrm{C}$ и $50^{\circ} \mathrm{C}$ (отмеченные зависимости приводятся в обзоре, в работе [9]):

$$
t_{\mathrm{o}}=[\sigma] \cdot\left(\mathrm{K} * \ln \left(\mathrm{T}_{\text {пл }}\right)+\mu 20 / \mu 50\right)
$$

где $[\sigma]$ - поправочный коэффициент (оС/\%); $\mu 20$ - кинематическая вязкость нефти при $20^{\circ} \mathrm{C}\left(\right.$ мм $\left./ \mathrm{c}^{2}\right), \mu 50$ - кинематическая вязкость нефти при $50^{\circ} \mathrm{C}\left(\right.$ мм $\left./ \mathrm{c}^{2}\right), \mathrm{K}$ - суммарное содержание парафинов, смол и асфальтенов (\%), $\mathrm{T}_{\text {пл }}$ - температура плавления выделенного из нефти парафина $\left({ }^{\circ} \mathrm{C}\right)$. В работе [9] приводятся результаты расчетов температуры насыщения парафином нефти по этим выражениям.

Авторами [8] на установке Flass (Vinci Technologies), предназначенной для изучения процессов образования твердых веществ в пластовом флюиде, был проведен эксперимент по определению температуры насыщения нефти парафином (изобарное снижение температуры при давлении 24 МПа). Для оценки влияния содержания в нефти смол на температуру насыщения ее парафином в результате обработки данных наблюдений были получены две модели, отличающиеся друг от друга содержанием смол (при одинаковом содержании асфальтенов и парафинов).

Как показывает анализ отмеченных зависимостей, в различных их вариантах и разновидностях, к настоящему времени накопилось многочисленное количество таких зависимостей, полученных различными авторами. Полученные по различным выражениям данные в той или иной степени отличаются в связи с недоучетом некоторых факторов, однако в то же время они позволяют дать качественную оценку при сравнении нефтей различных месторождений. Так, по данным [9], нефть месторождения Узень обладает более высокой температурой насыщения парафином. Далее идут Кумколь и Акшабулак. Из посвященных составу трудноизвлекаемых нефтей работ следует, что отмеченная температура является одной из важных показателей, ее знание дает возможность определять интервал неблагоприятных температур в процессе добычи скважинной продукции, а также своевременно принимать решения по предотвращению накопления АСПО. Анализ результатов выполненных исследований показывает, что, несмотря на многочисленные исследования, изучение температуры насыщения парафином нефтей представляет интерес и в настоящее время. Однако это требует постановки исследований по обобщению и статистической обработке накопленного материала, а в случае необходимости и постановки дополнительных экспериментальных исследований.

Результаты исследований. Для подтверждения влияния содержания асфальтенов, смол и парафиновых отложений в нефти на температуру насыщения нефти парафином выполнены обобщение и анализ накопленных результатов экспериментальных исследований для Урало-Поволжья $[5,6,7,18]$. Для облегчения прогнозной оценки на основе рассмотренных частных зависимостей путем их обобщения и 
статистического анализа построена общая зависимость $t_{\text {пар }}=f\left(C_{a}, C_{c}, C_{n}\right)$. Здесь $t_{\text {пар }}-$ температура насыщения нефти залежей парафином; $C_{w}, C_{c}, C_{n}-$ концентрации асфальтенов, смол, высокомолекулярных парафинов соответственно, \%.

Для получения такой зависимости вначале выбраны аналитические аппроксимации частных зависимостей, которые впоследствии обобщены известными в математической статистике методами путем их переумножения. В результате отмеченных преобразований получено следующее уточненное выражение:

$$
\mathrm{t}_{\mathrm{H}}=7,2701 \mathrm{C}_{\mathrm{a}}^{-0,0837}\left(17,41 * \ln \left(\mathrm{C}_{\mathrm{\Pi}}\right)+1\right)^{0,3787} \mathrm{e}^{0,00855862 \mathrm{Cc}}
$$

Проведены расчеты по данному выражению и сравнение с экспериментальными данными, приведенными в [5,6]. Результаты приведены в таблице 1.

Как видно из сравнения расчетных и экспериментальных данных, с достаточной степенью их можно считать близкими и зависимость, таким образом, можно считать приемлемой для района исследований. Представляет интерес изучение аналогичной связи для условий Казахстана. Для этой цели можно сделать попытку идентификации полученного выражения к условиям месторождений Казахстана или построения такой же зависимости по данным экспериментальных исследований для нефтей месторождений Казахстана. Следует отметить, что, естественно, для этого нужны результаты специальных дополнительных исследований. В работе Ш. Аскаровой [9] со ссылкой на выполненные работы в обобщенном виде приведены результаты для пяти месторождений Казахстана. С использованием этих данных нами сделана попытка идентификации полученной зависимости к условиям Казахстана.

В работе [13] показано, что температура насыщения нефти парафином зависит, кроме содержания в ней парафина, наряду с содержанием смол и асфальтенов, от температуры плавления выделенного парафина из нефти, а также кинематической вязкости при $20^{\circ} \mathrm{C}$ и $50^{\circ} \mathrm{C}$.

На основании полученных экспериментальных данных, в работе [9] приводятся значения температур насыщения нефти парафином. С учетом отмеченного

Таблица 1 - Значения концентраций асфальтенов, смол, высокомолекулярных парафинов и соответствующие им температуры насыщения нефти парафинами (Урало-Поволжье),

по данным И.М. Амерханова

\begin{tabular}{|c|c|c|c|c|c|c|}
\hline $\mathbf{C}_{\mathbf{a}}$ & $\mathbf{C}_{\mathbf{c}}$ & $\mathbf{C}_{\mathbf{n}}$ & $\mathbf{t}_{\mathbf{н ~ р а с ч ~}}$ & $\mathbf{t}_{\mathbf{н ~ ф а к т ~ с р ~}}$ & $\boldsymbol{\Delta t}_{\text {набс }}$ & $\boldsymbol{\Delta t}_{\text {нотн }}$ \\
\hline 1,32 & 3,84 & 4,53 & 25,69 & 22,87 & 2,82 & 12,32 \\
\hline 0,53 & 9,76 & 3,28 & 26,74 & 25,45 & 1,29 & 5,06 \\
\hline 2,24 & 12,53 & 4,00 & 25,65 & 28,48 & 2,82 & 9,92 \\
\hline 0,61 & 15,03 & 4,12 & 29,44 & 28,95 & 0,5 & 1,72 \\
\hline 0,55 & 17,39 & 4,22 & 30,49 & 29,49 & 1 & 3,4 \\
\hline 0,41 & 13,73 & 3,13 & 27,82 & 30,9 & 3,08 & 9,97 \\
\hline 0,47 & 20,29 & 4,53 & 32,21 & 32,1 & 0,12 & 0,36 \\
\hline 0,63 & 17,65 & 7,19 & 33,90 & 34,20 & 0,30 & 0,88 \\
\hline
\end{tabular}




\section{НЕФТЕХИМИЯ}

и результатов, приведенных в используемой литературе, построена зависимость температуры насыщения нефти парафином, как от содержания асфальтенов, смол и парафина, так и соотношения вязкостей.

На рисунке 1 представлена полученная по данным работы [9] зависимость температуры насыщения нефти парафином от массового содержания в растворе парафинов, смол и асфальтенов.

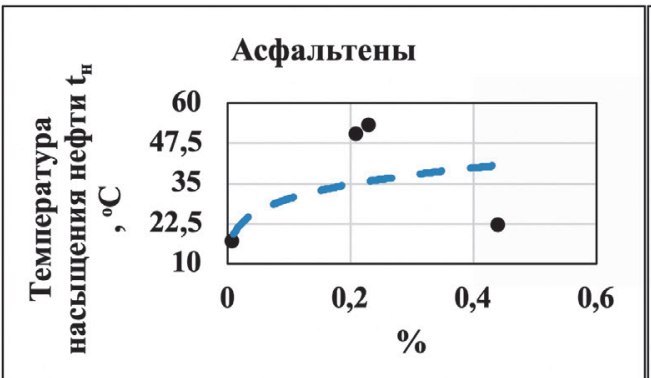

a)

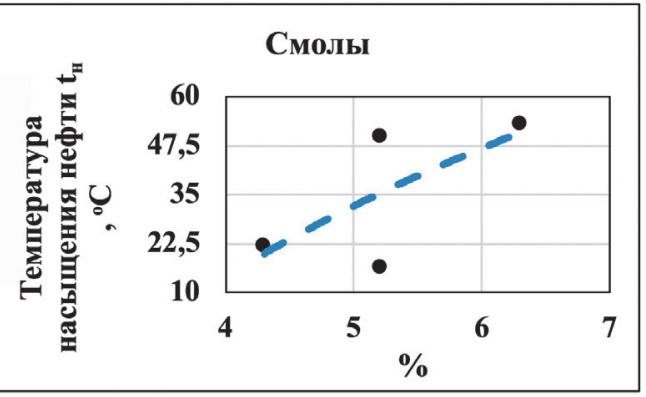

б)

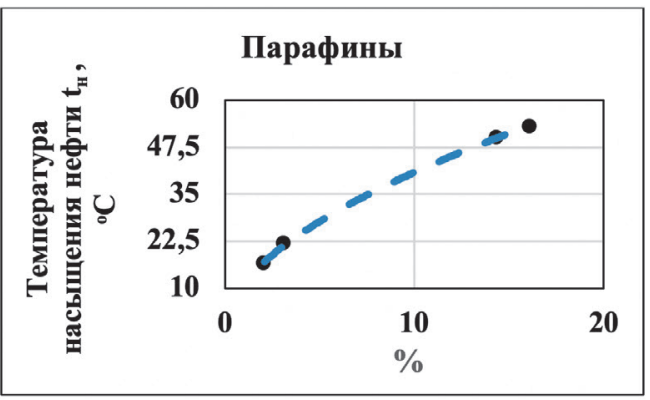

в)

Рисунок 1 - Влияние состава высокомолекулярных компонентов на температуру насыщения парафином нефти месторождений Казахстана: высокомолекулярные компоненты нефти: а - асфальтены, б - смолы; в - высокомолекулярные парафины, \%

$$
\mathrm{t}_{\mathrm{H}}=37,362 * \mathrm{C}_{\mathrm{a}}^{0,0855}\left(0,3363 \mathrm{C}_{\mathrm{c}}-1\right)^{0,4292} \mathrm{C}_{\Pi}^{0,2392}\left(0,6451 \frac{\mu_{20}}{\mu_{50}}-1\right)^{0,4292}
$$

В таблице 2 приведены исходные данные согласно [9], а также соответствующие расчетные значения температуры насыщения нефти парафином.

Заключение. Таким образом, расчеты по выражению (5) дают в целом достаточно удовлетворительные результаты. Отмеченное выражение может быть использовано при ориентировочных расчетах. При этом относительная погрешность колеблется в пределах 4 - 16\%, что позволяет применять выражение (5). Для получения более точных прогнозных данных о значениях температуры насыщения нефти парафином необходимы постановка и проведение более детальных, расширенных экспериментальных исследований. 
Таблица 2 - Исходные данные и соответствующие расчетные значения температуры насыщения нефти парафином

\begin{tabular}{|c|c|c|c|c|c|c|c|c|c|c|}
\hline \multirow{2}{*}{$\begin{array}{c}\text { Место- } \\
\text { рождение }\end{array}$} & \multicolumn{3}{|c|}{$\begin{array}{c}\text { Структурно-групповой } \\
\text { состав, \% }\end{array}$} & \multicolumn{2}{|c|}{$\begin{array}{c}\text { Вязкость } \\
\text { нефти, мм/ } \\
c^{2}\end{array}$} & \multirow{2}{*}{ 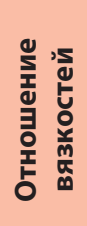 } & \multirow{2}{*}{ 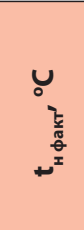 } & \multirow{2}{*}{ 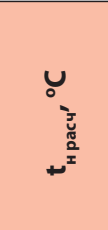 } & \multicolumn{2}{|c|}{ Погрешность } \\
\hline & $\begin{array}{c}\text { Асфаль- } \\
\text { тены }\end{array}$ & Смолы & $\begin{array}{l}\text { Пара- } \\
\text { фины }\end{array}$ & $\begin{array}{l}\text { при } \\
20^{\circ} \mathrm{C}\end{array}$ & $\begin{array}{l}\text { при } \\
50^{\circ} \mathrm{C}\end{array}$ & & & & $\begin{array}{l}\Delta t_{H} \\
\text { abc }\end{array}$ & $\Delta t_{\text {н отн }}$ \\
\hline Ботахан & 0,44 & 4,3 & 3,1 & 12,82 & 6,04 & 2,12 & 22 & 21,052 & 0,95 & 4,31 \\
\hline $\begin{array}{c}\text { Восточный } \\
\text { Макат }\end{array}$ & 0,01 & 5,21 & 2,1 & 11,2 & 4,98 & 2,25 & 16,67 & 18,919 & 2,25 & 13,49 \\
\hline Кумколь & 0,21 & 5,2 & 14,4 & 8,93 & 3,91 & 2,28 & 50 & 42,647 & 7,35 & 14,71 \\
\hline Акшабулак & 0,23 & 6,3 & 16,1 & 13,11 & 4,66 & 2,81 & 53 & 61,557 & 8,56 & 16,15 \\
\hline
\end{tabular}

Следует отметить, что знание температуры насыщения нефти парафином необходимо, а это в свою очередь позволит осуществлять контроль продукции в процессе добычи и принимать соответствующие необходимые решения по предотвращению и профилактике образования АСПО.

\section{ЛИТЕРАТУРА}

1 Обзор мирового опыта добычи трудноизвлекаемых запасов нефти битумы Венесуэлы, нефтяные пески Канады, сланцевая нефть в США. Российские перспективы. Сибирская нефть. Технологии. http://www.gazprom-neft.ru > files > journal > SNp100

2 Валиханов А.В. Разработка малопродуктивных коллекторов. - Казань: Таткнигоиздат, 1972. - 92 c. [Valihanov A.V. Razrabotka maloproduktivnyh kollektorov. - Kazan': Tatknigoizdat, 1972. - 92 s.].

3 Вахитов Г.Г., Термодинамика призабойной зоны нефтяного пласта. - М.: Недра, 1978. - 216 c. [Vahitov G.G., Termodinamika prizabojnoj zony neftyanogo plasta. - M.: Nedra, 1978. - $216 \mathrm{~s}$.]

4 Гавура В.Е. Геология и разработка нефтяных и газонефтяных месторождений. - М.: ВНИИОЭНГ, 1995. - 496 с. [Gavura V.E. Geologiya i razrabotka neftyanyh i gazoneftyanyh mestorozhdenij. - M.: VNIIOENG, 1995. - 496 s.]

5 Тупицин А. М. Извлечение вязкой нефти из сложно-построенных залежей комплексными технологиями вытеснения (на примере Байтуганского месторождения). Дисс. канд. наук, Бугульма, 2017, 145 с. [Tupicin A. M. Izvlechenie vyazkoj nefti iz slozhno-postroennyh zalezhej kompleksnymi tekhnologiyami vytesneniya (na primere Bajtuganskogo mestorozhdeniya). Diss. kand. nauk, Bugul'ma, 2017, 145 s.]

6 Амерханов И.М. Закономерности изменения свойств пластовых жидкостей при разработке нефтяных месторождений. Обзорная информация. Сер. Нефтепромысловое дело. - М.: ВНИИОЭНГ, 1980. - 49 с. [Amerhanov I.M. Zakonomernosti izmeneniya svojstv plastovyh zhidkostej pri razrabotke neftyanyh mestorozhdenij. Obzornaya informaciya. Ser. Neftepromyslovoe delo. - M.: VNIIOENG, 1980. - 49 s.] 
7 Амерханов И.М. Пластовые нефти Татарской АССР и изменения их параметров в зависимости от различных факторов. - Бугульма: ТатНИПИ, 1975. - 483 с. [Amerhanov I.M. Plastovye nefti Tatarskoj ASSR i izmeneniya ih parametrov $v$ zavisimosti ot razlichnyh faktorov. - Bugul'ma: TatNIPI, 1975. - 483 s.]

8 Коробов Г.Ю., Рогачев М.К. Исследование влияния асфальто-смолистых компонентов в нефти на процесс образования асфральтосмолопарафиновых отложений // Нефтегазовое дело. - 2015. - N 3. - C.162-173. [Korobov G.YU., Rogachev M.K. Issledovanie vliyaniya asfal'to-smolistyh komponentov $v$ nefti na process obrazovaniya asfal'tosmoloparafinovyh otlozhenij // Neftegazovoe delo. - 2015. - N 3. - C.162-173.]

9 Аскарова Ш. А. Новые модифицированные полиолефины для ингибирования асфральто-смоло-парафиновых отложений (АСПО) и очистки технологических нефтетрубопроводов. Диссертация на соискание степени доктора философии (PhD). Алматы, 2017. [Askarova Sh A. Novye modificirovannye poliolefiny dlya ingibirovaniya asfal'tosmolo-parafinovyh otlozhenij (ASPO) i ochistki tekhnologicheskih neftetruboprovodov. Dissertaciya na soiskanie stepeni doktora filosofii (PhD). Almaty, 2017.]

10 Бойко Г.И., Любченко Н.П., Сармурзина Р.Г., Касымгалиев К.М., Аскарова Ш.А. Результаты прогнозирования образования асфальто-смоло-парафиновых отложений на скважинах месторождений Западного Казахстана // Вестник Казахстанско-Британского технического университета. - 2015. -Vol.12. - No 3. - C.26-30. [Bojko G.I., Lyubchenko N.P., Sarmurzina R.G., Kasymgaliev K.M., Askarova SH.A. Rezul'taty prognozirovaniya obrazovaniya asfal'to-smolo-parafinovyh otlozhenij na skvazhinah mestorozhdenij Zapadnogo Kazahstana // Vestnik Kazahstansko-Britanskogo tekhnicheskogo universiteta. - 2015. -Vol.12. - No 3. - S.26-30.]

11 Глущенко В.Н. Силин М.А., Пташко О.А., Денисова А.В. Нефтепромысловая химия: Осложнения в системе пласт-скважина-УППН: учебное пособие. - М.: МАКС Пресc, 2008. - 328 c. [Glushchenko V.N. Silin M.A., Ptashko O.A., Denisova A.B. Neftepromyslovaya himiya: Oslozhneniya v sisteme plast-skvazhina-UPPN: uchebnoe posobie. - M.: MAKS Press, 2008. - 328s.]

12 Каменщиков Ф.А. Тепловая депарафинизация скважин. - Ижевск: НИЦ «Регулярная и хаотичная динамика», 2005. - 254 с. [Kamenshchikov F.A. Teplovaya deparafinizaciya skvazhin. - Izhevsk: NIC «Regulyarnaya i haotichnaya dinamika», 2005. - 254 s.]

13 Мисник В.В. Галикеев Р.М. Методика прогнозирования глубины образования асфальтосмолопарафиновых отложений в скважинах // Нефтегазовое дело. - 2011. - № 6. -C. 345-349. [Misnik V.V. Galikeev R.M. Metodika prognozirovaniya glubiny obrazovaniya asfal'tosmoloparafinovyh otlozhenij v skvazhinah // Neftegazovoe delo. - 2011. - No 6. - S. 345-349.]

14 Глущенко В.Н. Предупреждение и устранение асфальтеносмолопарафиновых отложений. Нефтепромысловая химия. - М.: Интерконтракт Наука, 2009. - 475 с. [Glushchenko V.N. Preduprezhdenie i ustranenie asfal'tenosmoloparafinovyh otlozhenij. Neftepromyslovaya himiya. - M.: Interkontrakt Nauka, 2009. - 475 s.]

15 Мордвинов В.А. Методика оценки глубины начала интенсивной парафинизации скважинного оборудования. Нефтяное хозяйство. - 2010. - №7. - С. 112-115. [Mordvinov V.A. Metodika ocenki glubiny nachala intensivnoj parafinizacii skvazhinnogo oborudovaniya. Neftyanoe hozyajstvo. - 2010. - №7. - S. 112-115.]

16 Рагулин В.В. Исследования свойств асфальтосмолопарафиновых отложений и разработка мероприятий по их удалению из нефтепромысловых // Нефтепромысловое дело. - 2001. - №5. - С. 33-36. [Ragulin V.V. Issledovaniya svojstv 
asfal'tosmoloparafinovyh otlozhenij i razrabotka meropriyatij po ih udaleniyu iz neftepromyslovyh // Neftepromyslovoe delo. - 2001. - №5. - S. 33-36.]

17 Требин Г.Ф. Нефти месторождений Советского Союза: Справочник. - М.: Недра, 1980. -583 c. [Trebin G.F. Nefti mestorozhdenij Sovetskogo Soyuza: Spravochnik. - M.: Nedra, 1980. - 583 s.]

18 Агаева К.К., Каражанова М.К., Жетекова Л.Б., Смагулова Д.Б. Анализ методов изучения состава и свойств высоковязкой нефти // Оборудование и технологии для нефтегазового комплекса. - 2021. - №2 (122). - С. 69-74. [Agaeva K.K., Karazhanova M.K., Zhetekova L.B., Smagulova D.B. Analiz metodov izucheniya sostava i svojstv vysokovyazkoj nefti // Oborudovanie i tekhnologii dlya neftegazovogo kompleksa. - 2021. - №2 (122). - C. 69-74.] 